Vol. 23, No. 5

May 1999

ISSN 0955-6036

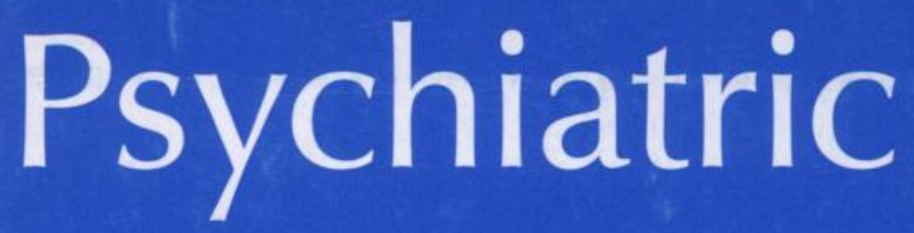

Bulletin

The Journal of Trends in Psychiatric Practice 


\title{
Psychiatric Bulletin
}

\section{The Journal of Trends in Psychiatric Practice}

\author{
Editor: Dr Tom Fahy \\ Editorial Board: Dr Derek Chiswick \\ Dr Louise Howard, Dr Peter Kennedy, Dr Rosalind Ramsay, \\ Dr Henry Rollin, Dr Mike Shooter, Dr David Tait. \\ Professor Peter Tyrer, Professor Greg Wilkinson \\ Bulletin Coordinator: Conceição Santos Sinclair \\ Assistant Scientific Editor: Zoë Stagg
}

\section{Notice to contributors}

The Psychiatric Bulletin publishes original scientific papers, brief review articles and opinion pleces dealing with treatment of mental disorders, administration, audit and management of psychiatric services and training in psychiatry. The Psychiatric Bulletin focuses on matters relevant to everyday clinical practice and management in psychiatry. The Psychiatric Bulletin will prioritise articles which are of practical clinical relevance, topical and accessible.

All original articles are peer reviewed. Authors should send three copies of their submission, typed doublespaced with wide margins, and give a total word count. A good length is 1500 words. Longer papers are likely to be returned to the authors for editing before being sent to referees. A structured abstract of $100-120$ words (headings to include aims and method, results and clinical implications) should be included with all original scientific papers. A summary of approximately 100 words should precede review articles. Authors are encouraged to limit the number of tables/figures to a maximum of three. Photographs and illustrations are welcome. For more detailed advice on referencing (Harvard system). presentation of statistical information and the style of tables and figures. please refer to instructions to authors in the British Journal of Psychiatry.

Papers on audit must demonstrate a completed audit cycle. Correspondence is welcome: letters should be no longer than 250 words (please give word count) and include no more than three references, and no tables or diagrams. Letters can be e-malled to csantossinclair@rcpsych.ac.uk. The correspondence editor will use a standard letter to inform authors if their letter is to be published or not. Books reviews should be no longer than 500 words.

If an individual patient is described, the patient should read the report before submission, and written consent must be obtained from the patient or an authorised person. Contributors should be aware of the risk of complaint by patients in respect of defamation and breach of confidentiality.

All material submitted should be accompanied by a covering letter to the editor signed by all authors. Contributions are accepted for publication on the condition that their substance has not been published or submitted elsewhere.

The Psychiatric Bulletin is published monthly by the Royal College of Psychiatrists, 17 Belgrave Square. London SW IX 8PG. (Registered charity no. 228636.)

\section{Subecriptions}

Non-members of the College should contact the Publications Subscriptions Department, Royal Society of Medicine Press Limited. 1 Wimpole Street, London WIM $8 A E$ (tel. 0171290 2928).

Subscription rate for 1999: $£ 55$ (UK and elsewhere). \$81 (USA).

The paper used in this publication meets the minimum requirements of American National Standard for Information Sciences-Permanence of Paper for Printed Lbrary Materials. ANS1 Z39. 48-1984.
Psychiatric Bulletin is covered by the Excerpta Medica database EMBASE.

US Mailing Information: The Psychiatric Bulletin is published monthly by the Royal College of Psychiatrists. Subscription price is $\$ 81$. Second Class postage paid at Rahway. NJ. Postmaster send address corrections to Psychiatric Bulletin. c/o Mercury Airfreight International Ltd Inc., 365 Blair Road, Avenel. New Jersey 07001.

\section{ISSN 0955-6036.}

Typeset by Dobble Typesetting Limited. Tavistock. Printed in Great Britain by Henry Ling Ltd, at the Dorset Press, Dorchester, Dorset.

Information about the College's publications is avallable on the World Wide Web at http://www.rcpsych.ac.uk. (C) 1999 The Royal College of Puychiatriots. Unless so stated, material in the Psychiatric Bulletin does not necessartly reflect the views of the editor or the College. The publishers are not responsible for any error of omission or fact. 


\section{Editorial}

Acute hospital care: ineffective, inefficient and poorly organised.

$$
\text { M. Muijen }
$$

\section{Review article}

Disability and incapacity benefits. The role that doctors play.

$$
\text { M. Killoughery }
$$

\section{Original papers}

Psychiatric features of new variant Creutzfeldt-Jakob disease. R. G. Will,

\section{G. Stewart, M. Zeidler, M. A. Macleod and R. S. G. Knight}

Survey of suicides in the Fife region of Scotland. F. Douds and V. Bridges

Adolescent counselling services in the voluntary sector. M. Mitchell

Readability of user leafets. H. Humfress and U. Schmidt

Traditional healers and mental illness in Uganda. E. Ovuga, J. Boardman and E. G. A. O. Oluka

Performance in psychiatry undergraduate finals. The influence of gender and nationality. R. Cullivan, S. Rooney, G. Kelly and N. Walsh

Psychiatric training of pre-registration house officers.

$$
\text { J. M. O'Dwyer }
$$

\section{Special articles}

Henry R. Rollin. In conversation with Alan Kerr.

Fertile Imaginations: an inner city allotment group. J. Seller, J. Fieldhouse and M. Phelan

Academic psychiatry in the Deep South. T. Mahmood and S. Romans

\section{Education and training}

Management training as a senior specialist/registrar. M. F. Bowden

Visit to the Gaza Community Mental Health Programme: training in child mental health. A. Aziz Thabet and P. Vostanis

Correspondence

The College

Inquiry Report recommendation

Proposal for a Special Interest Group in Spirituality and Psychiatry

Proposal for a Special Interest Group in Psychopharmacology

Council reports

Obituaries

Book review

Miscellany

Forthcoming events 